\title{
Looking through glassfish: marine genetic structure in an estuarine species
}

\author{
Courtenay E. Mills ${ }^{A^{*}}$, Wade L. Hadwen ${ }^{A}$ and Jane M. Hughes ${ }^{A}$ \\ 5 A Australian Rivers Institute, Griffith University, Nathan, QLD 4111, Australia \\ * Corresponding author: Tel: +61 737356660
}

Email: courtenay.mills@griffith.edu.au

Abstract. Through the use of mitochondrial DNA (ATP8 gene), the prediction of intermediate genetic structuring was investigated in two species of estuarine glassfish (Ambassis marianus (Günther 1880) and Ambassis jacksoniensis (Macleay 1881)) (Perciformes: Ambassidae) to determine the possibility of a generalised 'estuarine' genetic structure. Individuals were collected from estuaries in eastern Australia between Tin Can Bay (Queensland) in the north and Kempsey (New South Wales) in

15 the south. Analysis of the haplotype frequencies found in this region suggested panmictic populations with star-like phylogenies with extremely high levels of genetic diversity, but with no correlation between geographic distance and genetic distance. Non-significant $F_{\mathrm{ST}}$ and $\Phi_{\mathrm{ST}}$ suggested extensive dispersal among estuaries. However, Tajima's $D$ and Fu's $F_{\mathrm{S}}$ values suggest 'mutation - genetic drift equilibrium' has not been reached, and that population expansions occurring 262000 (A. marianus) and 300000 (A. jacksoniensis) years ago may obscure any phylogeographic structuring or isolation by distance. The finding of panmixia was contrary to the prediction of genetic structuring intermediate between that of marine fish (shallowly structured) and freshwater fish (highly structured), suggesting high dispersal capabilities in these 25 species. 
Extra Keywords: Estuaries, phylogeography, ambassid.

\section{INTRODUCTION}

When considering the differences between freshwater and marine populations, 30 generalized patterns of genetic structure can often be observed (Feral 2002). Numerous studies have investigated phylogeographic structuring of mitochondrial DNA (mtDNA) in freshwater and marine systems to describe the relationships between geographic and genetic distances and their concordances and discordances (Waters et al. 2000; Baker et al. 2004; Ovenden and Street 2003; Page et al. 2004;

35 Huey et al. 2006). In general, marine populations tend to be shallowly structured and freshwater systems strongly structured (Bilton et al. 2002; Wong et al. 2004). Studies of freshwater species such as brook charr (Castric et al. 2001), hardyheads (McGlashan and Hughes, 2000), perch (Nesbo et al. 1998) and pygmy perch (Cook et al. 2007) are among many to have exemplified strong patterns of structure with high

$40 \quad F_{\mathrm{ST}}$ values. In contrast, a study by Ward and Elliot (2001) of 20 marine species in south eastern Australia detected structuring in only four of these species.

As physical connectivity can heavily influence population structure, marine populations are characterized by shallow structure, with tidal action and currents

45 facilitating the homogenization of gene frequencies (Avise 1998; Watts and Johnson 2004; Sheaves et al. 2007). Particularly in marine populations where 'mutation genetic drift equilibrium' has been reached, any observed structure often shows a pattern of 'isolation by distance' (IBD), where there is a positive relationship between genetic distance between sites and geographic distance between them (Wright 1943;

50 Slatkin and Maddison 1990). Additionally, dispersal in adults, juveniles and larvae is 
relatively unimpeded by physical barriers, allowing for the free transfer of genes from population to population (Ward and Elliot 2001). In contrast, genetic structure in freshwater organisms tends to be dominated by gene frequencies that can often be quite distinct from neighboring populations (Cook et al. 2006; Ponniah and Hughes 55 2006). Hydrological connectivity in Australian freshwater systems in particular is often highly variable, with periods of low flow often disconnecting pools and reducing opportunities for gene flow (Huey et al. 2006). As a result, freshwater populations isolated from gene flow develop distinct haplotype frequencies though the process of genetic drift and environment-specific selection (Hurwood and Hughes 2001).

The east coast of Australia is characterized by small coastal streams, open estuaries and intermittently closed and open lakes and lagoons (ICOLLs) (Hadwen et al. 2007). Most of these estuarine systems are geomorphically young and were formed in the last

656000 years (Chappell 1982). As constantly changing geomorphic features and highly productive ecosystems, estuaries are significant in the life cycles of numerous aquatic species, especially in providing nursery habitat (Vrijenhoek 1998; Edgar et al. 2000; Able 2005).

70 As estuaries represent the ecotone between marine and freshwater systems, it has been suggested that estuarine fish may be expected to have levels of gene flow that are intermediate to those observed in marine and freshwater environments (DeWoody and Avise, 2000). Organisms in estuarine environments are typically adapted to highly variable conditions, such as fluctuating salinity and temperature (Bilton et al. 2002; 75 Cook et al. 2006). Furthermore, estuarine fish utilize a variety of dispersal 
mechanisms which can strongly influence patterns of gene flow (Slatkin 1987; Doherty et al. 1994; Doherty et al. 1995). Many aquatic species have several life stages that can have a distinct role in the flow of genes in and between populations (Grantham et al. 2003; Nathan 2005). Passive dispersal in the larval stage is often the 80 crucial phase for gene flow in fish (Panov et al. 2004). This is particularly true for many estuarine and marine species where larvae are carried by tidal action and currents (often over many hundreds of kilometers) to recruit into new populations (Doherty et al. 1995; Riginos and Nachman 2001; Hamer and Jenkins 2004). However, the effectiveness of this mechanism for dispersal is dependent upon the 85 duration of the larval phase, where the longer the larval phase, the greater the potential dispersal distance (Uthicke and Benzie 2003).

Many studies of marine systems exemplify IBD, particularly where the species distribution is expansive (Emerson et al. 2001). IBD is expected to characterise 90 population structure where 1) the sampling range is smaller than the distribution of the population, and 2) the sampled population is in equilibrium between mutation, gene flow and drift (Slatkin and Maddison 1990; Slatkin 1993). Given that the distribution of many marine species can cover large areas of coast and ocean, it is not surprising that populations of turbot (Feral 2002), greenback flounder (Ward and Elliot 2001) 95 and Australian bass (Chenoweth and Hughes (1997) have all shown structure following models of IBD. Due to the large, linear distribution of Ambassis marianus (A. marianus) and Ambassis jacksoniensis (A. jacksoniensis) it seems likely that these populations will be characterised by IBD. 
Ambassis marianus and Ambassis jacksoniensis (Ambassidae) are two species of estuarine glassfish endemic to the east coast of Australia (Allen and Burgess 1990; Hurst et al. 2005). Both species are abundant schooling fish, and can be found in both clear and turbid small coastal streams, permanently open large estuarine rivers and ICOLLs (tolerating salinities of up to 35) (Hurst et al. 2005). The distribution of these ambassids is reported to extend from Sydney (New South Wales (NSW), Australia) to Hervey Bay (Queensland (QLD), Australia) (Allen et al. 2002). A. marianus and A. jacksoniensis are relatively small fish, commonly growing to about $60 \mathrm{~mm}$ in length (Allen et al. 2002). They are very similar morphologically; however a few key features distinguish them from one another. As typical of ambassids, the bodies of

110 both species are transparent and have a vivid, reflective stripe running along the lateral line (Pusey et al. 2004). Fins are generally pale and transparent, although some A. marianus specimens collected in this study exhibited pale yellow colouring. $A$. marianus is easily identifiable by the dorsal fin, as the first spine is black, whereas dorsal spines in A. jacksoniensis are generally uncoloured (Allen and Burgess 1990).

115 A. jacksoniensis is also more slender in body shape than A. marianus, as the latter has more breadth longitudinally, and also has a greater spine to body size ratio (Allen and Burgess 1990). Very little is known of either of these species in regards to their life history.

120 This study aimed to examine the genetic partitioning found in A. marianus and $A$. jacksoniensis, and investigate any correlations with geographic influences. It was hypothesised that the populations of two study species would exhibit structuring characterised by IBD (Wright 1943). Furthermore, this study explored the possibility of 'intermediate gene flow' (i.e. levels of gene flow between that of marine and 
125 freshwater fish), which has been suggested for estuarine systems (Farrington et al. 2000; Dawson et al. 2002; Cabral et al. 2003; Watts and Johnson 2004; Doukakis et al. 2005).

\section{MATERIALS AND METHODS}

130

\section{Field Collection}

Individuals were collected from 23 estuarine systems along the east coast of Australia, from Crab Creek (Tin Can Bay, QLD) in the north, to the Macleay River (Kempsey, NSW) in the south, during field trips in 2006 and early 2007 (Figure 1). Sites in QLD represented most of the estuarine habitats along the coast, whereas sites in NSW were restricted only to estuarine locations specified under the issued NSW Scientific Research Permit. Three types of estuarine systems were sampled - 1) small coastal creeks, 2) permanently open large estuarine rivers, and 3) ICOLLs. Abundance and occurrence of species fluctuated markedly from site to site, resulting in lower (or no)

140 samples for some sites (Tables 3 and 4). Individuals ranged in size from $10 \mathrm{~mm}$ to $80 \mathrm{~mm}$, and thus included juveniles and adults. Collection was carried out using a seine net ( $15 \mathrm{~m}$ long and $2 \mathrm{~m}$ high (with a $2 \mathrm{~m}$ long bag), with a 9-mm mesh size) operated by two people. Non-target species were immediately returned to the point of capture, as were surplus individuals of the target species (if any). Individuals required 145 for analysis were euthanised in an ice slurry and stored in liquid nitrogen, then at $80^{\circ} \mathrm{C}$ until required for processing. 
Species identification was made through the use of keys and sequence differences, especially in the case of juveniles (Allen and Burgess 1990). Total genomic DNA was extracted from each individual using a variation of the CTAB (cetyl trimethyl ammonium bromide) phenol-chloroform extraction procedure (Doyle and Doyle

155 1987). The polymerase chain reaction (PCR) was used to amplify the ATP8 mtDNA region to produce a fragment of 414 base pairs using the ATP8.2 and COIII.2 primers (ATP8.2: 5'-AAA GCR TYR GCC TTT TAA GC-3'; COIII.2: 5'-GTT AGT GGT CAK GGG CTT GGR TC-3') (S. McCafferty, unpublished data). Amplification occurred in $12.5 \mu \mathrm{L}$ reactions of primers ATP8.2 and COIII.2 (0.5 $\mathrm{L}$ of each), double-

160 distilled water $(\mathrm{ddH} 2 \mathrm{O} ; 7.95 \mu \mathrm{L})$, extracted DNA $(1.0 \mu \mathrm{L})$ and Fisher Biotec's $10 \mathrm{x}$ reaction buffer $(1.25 \mu \mathrm{L})$ (www.fisherbiotec.com), $\mathrm{MgCl}_{2} \quad[25 \mathrm{mM}] \quad(1.0 \mu \mathrm{L})$, deoxynucleotide triphosphate (dNTPs $[10 \mathrm{mM}](0.25 \mu \mathrm{L}))$, and Taq [5.5 units $/ \mu \mathrm{L}]$ $(0.05 \mu \mathrm{L})$. Samples were subjected to the following conditions: $94^{\circ} \mathrm{C}$ for five minutes; 40 cycles of: $94^{\circ} \mathrm{C}$ for 30 seconds, $50^{\circ} \mathrm{C}$ for 30 seconds, and $72^{\circ} \mathrm{C}$ for one minute;

165 then $72^{\circ} \mathrm{C}$ for five minutes. Samples were then stored at $4^{\circ} \mathrm{C}$ until required for further analysis. The resulting PCR product was purified with exo-sap (Fermentas exonuclease $(20 \mathrm{u} / \mu \mathrm{L})$ (www.fermentas.com)) and shrimp alkaline phosphatase $(1 \mathrm{u} / \mu \mathrm{L}))$ where $5.0 \mu \mathrm{L}$ of PCR product was added to $0.5 \mu \mathrm{L}$ exo and $2.0 \mu \mathrm{L}$ sap, then samples underwent a thermal program $\left(37^{\circ} \mathrm{C}\right.$ for 35 minutes, $80^{\circ} \mathrm{C}$ for 20 minutes $)$ in

170 a GeneAmp PCR System 2700 (Applied Biosystems www.appliedbiosystems.com). Samples were held at $4^{\circ} \mathrm{C}$ until required for further analysis.

Purified mtDNA samples were sequenced using the ATP8.2 primer $(0.32 \mu \mathrm{L})$ in a 10 $\mu \mathrm{L}$ reaction also containing $5 \mathrm{X}$ sequencing reaction buffer $(2.0 \mu \mathrm{L}), 3.1$ Big Dye 


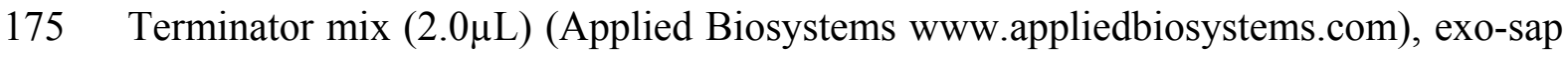
product $(0.5 \mu \mathrm{L})$ and $\mathrm{ddH}_{2} \mathrm{O}(5.18 \mu \mathrm{L})$. Again, this mixture was placed in a GeneAmp PCR System 2700 under the following thermal program: $96^{\circ} \mathrm{C}$ for one minute; then 30 cycles of: $96^{\circ} \mathrm{C}$ for 10 seconds, $50^{\circ} \mathrm{C}$ for 5 seconds, $60^{\circ} \mathrm{C}$ for four minutes. Samples were stored at $4^{\circ} \mathrm{C}$. Final reactions were cleaned then sequenced using the Applied Biosystems 3130xl Genetic Analyser (www.appliedbiosystems.com).

\section{Data Analysis}

Individual sequences were aligned and edited using Sequencher 4.1 (Gene Codes 2000) for sequence comparison. A final fragment of 414bp was selected for analysis,

185 and each species was analysed as a separate entity at all times. The TCSv1.21 program (Clement et al. 2000) was used to construct parsimonious networks showing relationships between haplotypes for each species, using the $95 \%$ most plausible connections. Arlequin v3.1 (Schneider et al. 2000) was used for calculations of overall $F_{\mathrm{ST}}$, a measure of genetic differentiation (Weir and Cockerham 1984) and $\Phi_{\mathrm{ST}}$, a test

190 of correlation between genetic divergence and genetic distance (Excoffier et al. 1992) among populations (Excoffier et al. 2005). Mantel tests in Arlequin v3.1 (Excoffier et al. 2005) were also used to perform correlations between genetic and geographic distance as an indicator of IBD. This procedure used Slatkin's Linearised $F_{\mathrm{ST}}\left(F_{\mathrm{ST}}=\right.$ $1 /\left(1-F_{\mathrm{ST}}\right)($ Slatkin 1995) as genetic distance, and geographic distance was determined

195 as being the linear distance between pairs of estuaries, via the ocean.

To ascertain whether the study populations were in mutation - genetic drift equilibrium, tests of neutrality were performed using the software package DnaSP 4.10.9 (Rozas and Rozas 1999). DnaSP 4.10.9 was also used to calculate the numbers 
of synonymous and non-synonymous base changes in sequences (Rozas and Rozas 1999). As star-like haplotype networks may be indicative of a recent population expansion, two tests of neutrality (Tajima's $D$ and Fu's $F_{\mathrm{S}}$ ) were used to analyse the two species for the expected frequencies of mutations in the populations (Chenoweth and Hughes 2003). Tajima's $D$ values and Fu's $F_{\mathrm{S}}$ values were generated to determine

205 whether observed mutations reflected that of expanding populations, or populations under selection (Rozas and Rozas 1999). Mismatch distributions were calculated from pairwise differences - differences between sequences (Harpending et al. 1993). Raggedness indices $(r)$ (which range between 1 and 0 ) were also computed in DnaSP to test whether observed mutational distributions were generated by stable or 210 expanding populations (Harpending et al. 1993). From this, Tau was used in estimating the time since population expansion, using the formula: Tau $=2 \mu \mathrm{t}$, where $\mathrm{t}$ is time in generations (one/year) and $\mu$ is the mutation rate, per sequence, per generation (Harpending et al. 1993). Sequence divergence in the fish ATP region has been estimated to be $1.3 \%$ per million years, therefore, the mutation rate is half this at $2150.65 \%$ per million years (Bermingham et al. 1997).

\section{RESULTS}

\section{Patterns of Variation}

220 Of the mtDNA ATP8 gene, $414 \mathrm{bp}$ were analysed from 98 A. marianus individuals and 149 A. jacksoniensis individuals. This revealed 1 non-synonymous and 18 synonymous changes for A. marianus, and 2 non-synonymous and 40 synonymous changes for A. jacksoniensis. Analysis of the 414 bp revealed 21 haplotypes in $A$. marianus (lodged under GenBank Accession Numbers: EU257288-EU257308), and 
22549 haplotypes in A. jacksoniensis (lodged under GenBank Accession Numbers: EU257313-EU257361) (Figs 2, 3 and Tables 3 and 4). Of these haplotypes, 8 of $A$. marianus and 10 of $A$. jacksoniensis were shared, and 13 of $A$. marianus and 39 of $A$. jacksoniensis were singletons (Tables 3 and 4). In both species, the arrangements of these haplotypes represented that of star-like phylogenies, radiating outwards from

230 several common internal haplotypes (Figs 2 and 3). Unresolved loops in the networks were dissolved following the guidelines of Posada and Crandall (2001), given the improbabilities of homoplasy and recombination in mitochondrial DNA (Sanderson and Donoghue 1989). Overall values of $F_{\mathrm{ST}}(0.019 ; \alpha=0.05 P=0.205$ for $A$. marianus, $0.017 ; \alpha=0.05 P=0.124$ for $A$. jacksoniensis $)$ and $\Phi_{\mathrm{ST}}(0.013 ; \alpha=0.05 P=0.300$ for $\mathrm{A}$.

235 marianus, $0.020 ; \alpha=0.05 P=0.106$ for A. jacksoniensis) were non-significant (Table 1 ). High levels of gene flow were indicated as the scale of $F_{\mathrm{ST}}$ and $\Phi_{\mathrm{ST}}$ ranges from 1 (complete population isolation) to 0 (panmixia). Mantel tests of the relationship between geographic distance and genetic distance were also non-significant $(A$. marianus $0.081 ; \alpha=0.05 P=0.238$ and A. jacksoniensis $0.107 ; \alpha=0.05 P=0.106$ ) (Table 240 1).

\section{Tests of Neutrality}

Both tests of neutrality yielded highly significant results (Table 2). Of particular interest were values produced for Fu's $F_{\mathrm{S}}$, as this test is particularly sensitive to the 245 signature of population expansion $(\mathrm{Fu} 1997)$. Fu's $F_{\mathrm{S}}$ values of $-12.779(\alpha=0.02$ $P=0.000)$ (A. marianus) and $-72.737(\alpha=0.02 P=0.000)($ A jacksoniensis $)$ indicated excess numbers of mutations in these populations. Tajima's $D$ values (A. marianus, $1.429(\alpha=0.05 P=0.046) ;$ A . jacksoniensis, $-2.364(\alpha=0.05 P=0.000))$ also supported this finding. 


\section{Mismatch Distributions and Expansion Dates}

Mismatch distributions of pairwise differences in the populations closely followed models based on expanding populations (Table 2). Raggedness indices for $A$. marianus $(0.020 ; \alpha=0.05 P=0.083)$ and A. jacksoniensis $(0.069, \alpha=0.05 P=0.933)$

255 showed no significant difference from the expected frequencies of mutations in expanding populations. Estimations of the time elapsed since these expansions were calculated with Tau, where values were 1.410 and 1.617 for $A$. marianus and $A$. jacksoniensis respectively. These values resulted in very similar estimates of time since expansion for A. marianus ( 262kya) and A. jacksoniensis ( 300kya).

\section{DISCUSSION}

\section{High genetic diversity - no structure}

Both A. marianus and A. jacksoniensis were found to have high levels of haplotype 265 diversity (Table 3 and 4), which is typical of marine fish, for example mangrove jack (Ovenden and Street 2003), mackerel, chub mackerel (Zardoya et al. 2004) and damselfish (Domingues et al. 2005). However, this diversity was not partitioned according to the geographic scale of the study, indicating panmixia (that is the genetic diversity contained within the population is homogenous on the geographic scale)

270 (Figs 2 and 3). This implies high dispersal capabilities in these species, with no apparent barriers to gene flow. Although previous studies suggest that 'intermediate' structuring is often observed in estuarine organisms, the results of this study suggest estuarine ambassids are structured in a manner commonly found in marine fish (Chaplin et al. 1998; Beheregaray and Sunnucks 2001; Watts and Johnson 2004). 
The high levels of diversity and the star-shaped phylogeny in both species are consistent with a relatively recent population expansion, where 1) sufficient generations have occurred to allow for divergence from ancestral haplotypes, and 2) genetic drift and selection have not yet purged the population of singletons and other 280 less common haplotypes (Posada and Crandall 2001). The high levels of diversity in both species indicate that most of the variation detected in the ATP8 region is neutral. In coding genes, most mutations are synonymous and do not affect protein function and the amino acid produced (Altukhov and Salmenkova 2002). This is observed in the genetic diversity of both A. marianus and A. jacksoniensis, where high levels of 285 mutations are persisting in both populations which suggests selection is not operating against lethal mutations.

Star-like networks are considered to be a signature of a recent population expansion, usually following a bottleneck or founder event (Chenoweth and Hughes 2003).

290 Coalescent theory suggests interior haplotypes are ancestral in the population and that tip haplotypes are more recent mutations and are therefore unlikely to be as widespread in the population (Figure 2 and 3) (Posada and Crandall 2001). The population may have also been small and stable historically, but changes in some factor (such as changes in temperature, sea level or geographic composition) may 295 have led to the population increase (Hewitt 2000). However, while these populations show no evidence of genetic structuring, the occurrence of a population expansion may act to obscure structure in the population, particularly recent expansions. Secondly, as recently expanded populations, it is unlikely these study species have been able to reach equilibrium between the effects of gene flow and genetic drift 
300 (Crow and Aoki 1984). Consequently, under these conditions, the absence of genetic structure may be due to excess mutations in the population giving the appearance of high gene flow. We acknowledge that this study contains low sample sizes for some sites, but we believe that increasing the sample size would have little effect on the overall conclusion. For each species, there is a single common haplotype shared

305 across all sites in similar frequencies. The rare singleton haplotypes have little effect on the overall $F_{\mathrm{ST}}$ values.

\section{Effects of life cycle on gene flow}

Whether dispersal and gene flow in A. marianus and A. jacksoniensis is facilitated by

310 adults, juveniles or larvae (or all) is unknown (Allen 1991). Hadwen and Arthington (2007) provided evidence of adult $A$. marianus recruitment into an ICOLL in northern NSW which suggests that adults can be vectors of gene flow. However, as a small estuarine-dwelling fish, with perhaps limited capability for traversing long sections of open ocean as adults, it seems likely that major dispersal events occur with larval fish

315 being passively transported and consequently recruited into new estuaries by currents and tidal cycles (Riginos and Nachman 2001). The differing effects of larval dispersal duration have been highlighted in a study of two marine fish by Purcell et al. (2006). They revealed that fish with a shorter larval pelagic time showed population structuring, whereas, longer larval durations corresponded with panmixia. Doherty et al. (1995) found the same relationship in a study of seven species, where shorter larval durations correlated with increased genetic structure. Whilst duration of the larval phase in A. marianus and A. jacksoniensis is not known, it is plausible that these species have a substantial larval duration that facilitates passage over considerable dispersal distances. Therefore, while local movements by adult fish may aid in 
325 homogenising alleles, it seems likely that long distance dispersal occurring in the larval stage may be the primary influence on allele frequencies in these species (Uthicke and Benzie 2003).

While larval dispersal is the most likely explanation for the observed haplotype 330 distributions in these species, there are other factors may result in panmixia. For example, Farrington et al. (2000) found similar patterns of panmixia in populations of black bream (Acanthopagrus butcheri); and that it was the adult individuals dispersing and facilitating gene flow, rather than larvae.

\section{Isolation by distance}

Neither species of ambassid showed evidence of IBD structuring (Table 1), and fitted Category IV of Avise et al. (1987) with haplotypes widely distributed and showing no relationship with geography (Figs 2 and 3). Given the connectivity and high levels of dispersal found in these populations of ambassids, and the abundance of the species, it

340 is not surprising that equilibrium in these populations has not yet been reached. Because these populations were apparently panmictic and genetically homogenised, this suggests that gene flow is exceeding the effect of genetic divergence, masking any IBD effect (Purcell et al. 2006). As an endemic and abundant species occurring in a relatively small, continuous distribution, it is likely that long distance dispersal can

345 counteract the effects of IBD (Doherty et al. 1995). This pattern is particularly common in coral reef fish, where adult individuals have a small dispersal range, but larvae disperse longer distances and homogenise gene frequencies (Bay et al. 2004; Klanten et al. 2007). 
Many population studies have shown population expansions coinciding with late Quaternary glacial retreats. In a study of tasselfish (Polynemus sheridani), Chenoweth and Hughes (2003) found recent post-glacial expansions across northern Australia associated with rising sea levels. Similarly, two species of West African estuarine fish

355 (Sarotheradon melanotheron and Ethmalosa fimbiata) underwent population expansions after periods of mainland aridity and low sea levels during a glacial cycle (Durand et al. 2005). In general, there is a common pattern of population expansions in many marine and estuarine fish species occurring toward the end of the more recent glacial cycles $(\sim 10000$ to 80000 years ago), which correspond with rising sea levels

360 (Uthicke and Benzie 2003; Domingues et al. 2005; O’Reilly et al. 2004; Bernatchez and Wilson 1998). However, expansion times of A. marianus and A. jacksoniensis greatly predate the majority of reported fish population expansions.

It is possible that an ice age depleted populations of $A$. marianus and A.jacksoniensis, 365 and that modern populations are the result of a population expansion after this era, when ice caps receded and seas levels rose (Hewitt 2000). The haplotype networks (Figs 2 and 3) suggest that the common haplotypes (J1 and M1) are representative of refugial populations that persisted through these periods of environmental change, from which contemporary populations have colonised new areas and diverged from parent haplotypes (Posada and Crandall 2001). However, since more recent ice ages and climate changes (occurring after the calculated time since population expansion) appear to have had little impact on the genetic diversity of these populations, this explanation may be questionable. An alternative explanation is that alternating sea levels generated bottlenecks within these populations, which have resulted in genetic 
375 structure that overrides any effects of more recent climatic alterations. Therefore, possible population expansions succeeding the initial event were insignificant in comparison, and not detected by the haplotypic resolution generated by this study. While plausible, it is difficult to identify specific geological events accounting for these population bottlenecks and expansions, particularly with limited geological data 380 specific to the study region. Finally, some recent studies of mutation rates in fish mitochondrial DNA, based on known geological changes in New Zealand, suggest that mutation rates may be much higher than currently thought (Burridge and Smolenski 2003; Burridge et al. 2006; Waters et al. 2006). Therefore we cannot totally discount the possibility that the expansions are much more recent than 385 calculated from our rate based on $0.65 \%$ per million years (Bermingham et al. 1997).

Population bottlenecks can be caused by a variety of factors other than glacial climate change. Changes in food web ecology where predator-prey interactions and interspecific competition alter can often devastate populations (Williamson 1993; 390 Maltagliata 2002). Disease can also bottleneck populations where a substantial proportion of the population perishes (Spear et al. 2006). Volcanic-induced environmental destruction and climatic alterations have also been attributed to reductions in population size (Hurwood and Hughes 1998; Hewitt 2000). In addition, founder events are also catalysts for population expansion where colonising 395 populations rapidly expand into new regions (Lacy 1987). Population expansions following founder events have been observed in many taxa, including freshwater shrimp (Paratya australiensis) (Cook et al. 2006), black bream (Acanthopagrus butcheri) (Chaplin et al. 1998) and tasselfish (Polynemus sheridani) (Chenoweth and Hughes 2003). While one or a combination of these factors (including glacial-related 
400 climate change) may have had severe repercussions for populations of $A$. marianus and A. jacksoniensis, isolating the historical events responsible for population bottlenecks, founder events and expansions is difficult.

Assessment of the genetic structure of $A$. marianus and A. jacksoniensis revealed high 405 levels of genetic diversity in a panmictic distribution, indicative of high dispersal capabilities in these species. However, the conclusion of panmixia was accepted with caution as there is evidence to suggest that these populations are not in 'mutation genetic drift equilibrium', having undergone population expansions $\sim 262 \mathrm{kya}$ ( $A$. marianus) and $\sim 300 \mathrm{kya}$ (A. jacksoniensis). To strengthen the conclusions reached 410 through mtDNA studies of ambassids, it would be beneficial to supplement the data set with an additional marker. This would confirm patterns of dispersal and gene flow found in these populations and verify ATP8 neutrality ( $\mathrm{Fu}$ 1997). Furthermore, mitochondrial DNA only reflects dispersal and gene flow in females, so a nuclear marker such as microsatellites would determine whether dispersal is gender neutral 415 (Johnson 2000; Nathan et al. 2003).

Ambassis marianus and Ambassis jacksoniensis were used to investigate the prediction of intermediate population structure in estuarine fish. The genetic structure and distribution of these species suggested that these estuarine fish had population structures more like those expected for marine fish. This lack of population structure suggests these species have high dispersal capabilities, although recent population expansions may also have contributed to this impression of panmixia. 
The authors would like to thank Dan Schmidt and Joel Huey for helpful remarks on the initial manuscript, in addition to the two anonymous referees for their comments. James Fawcett, Ana Dobson and Nick Allan provided invaluable assistance in the field; and Matthew Baddock advised us with geological queries. The Griffith Geeks 430 gave support in many areas of this project. The Australian Rivers Institute provided research and travel funds. Fish were sampled under Griffith University ethics permit AES/02/06/AEC, NSW Scientific Research Permit P06/0050 and Queensland Fisheries Permit \#55263.

\section{REFERENCES}

Able, K. W. (2005). A re-examination of fish estuarine dependence: evidence for connectivity between estuarine and ocean habitats. Estuarine, Coastal and Shelf Science 64, 5-17.

440

Allen, G. R. and Burgess, W.E. (1990). A review of the glassfishes (Chandidae) of Australia and New Guinea. Records of the Western Australian Museum 34, 139206.

445 Allen, G. R. (1991). 'Field Guide To The Freshwater Fishes of New Guinea'. Madang, Papua New Guinea, Christensen Research Institute.

Allen, G. R., Midgley, H. and Allen, M. (2002). 'Freshwater Fishes of Australia'. Perth, Western Australian Museum and CSIRO Publishing. 
Altukhov, Y. P. and Salmenkova, E.A. (2002). DNA polymorphism in population genetics. Russian Journal of Genetics 38, 1173-1195.

Avise, J. C., Arnold, J., Ball, R.M., Bermingham, E., Lamb, T., Neigel, J.E., Reeb, C.A. and Saunders, N.C. (1987). Intraspecific phylogeography: the mitochondrial DNA bridge between population genetics and systematics. Annual Review of Ecology and Systematics 18, 489-522.

Avise, J. C. (1998). The history and purview of phylogeography: a personal reflection. Molecular Ecology 7, 371-379.

Baker, A. M., Hughes, J.M., Dean, J.C. and Bunn, S.E. (2004). Mitochondrial DNA reveals phylogenetic structuring and cryptic diversity in Australian freshwater macroinvertebrate assemblages. Marine and Freshwater Research 55, 629-640.

Bay, L.K., Choat, J.H., van Herwerden, L. and Robertson, D.R. (2004). High genetic diversities and complex genetic structure in an Indo-Pacific tropical reef fish (Chlorurus sordidus): evidence of an unstable evolutionary past? Marine Biology 144, 757-767.

Beheregaray, L. B. and Sunnucks, P. (2001). Fine-scale genetic structure, estuarine colonization and incipient speciation in the marine silverside fish Odontesthes argentinensis. Molecular Ecology 10, 2849-2866. 
Bermingham, E., McCafferty, S. and Martin, A.P. (1997). 'Fish biogeography and molecular clocks: perspectives from the Panamanian Isthmus'. In 'Molecular Systematics of Fishes'. (Eds. T. Kocher and C. Stepian). pp. 113-126. Academic Press, San Diego.

Bernatchez, L. and Wilson, C.C. (1998). Comparative phylogeography of Nearctic and Palearctic fishes. Molecular Ecology 7, 431-452.

Bilton, D. T., Paula, J. and Bishop, J.D.D. (2002). Dispersal, genetic differentiation and speciation in estuarine organisms. Estuarine, Coastal and Shelf Science 55, 937-952.

485

Burridge, C.P. and Smolenski, A.J. (2003). Lack of genetic divergence found with microsatellite DNA markers in the tarakihi Nemadactylus macropterus. New Zealand Journal of Marine and Freshwater Research 37, 223-230.

Burridge, C.P., Craw, D. and Waters, J.M. (2006). River capture, range expansion and cladogenesis: the genetic signature of freshwater vicariance Evolution 60, 10381049 .

Cabral, H. N., Castro, F., Linhares, D. and Alexandrino, P. (2003). Genetic differentiation of Solea solea (Linnaeus, 1758) and Solea senegalensis (Kaup, 1858), (Pisces : Pleuronectiformes) from several estuarine systems of the Portuguese coast. Scientia Marina 67, 43-52. 
Castric, V., Bonney, F. and Bernatchez, L. (2001). Landscape structure and hierarchical genetic diversity in the brook charr, Salvelinus fontinalis. Evolution 55, 1016-1028.

Chaplin, J. A., Baudains, G.A., Gill, H.S., McCulloch, R. and Potter, I.C. (1998). Are assemblages of black bream (Acanthopagrus butcheri) in different estuaries genetically distinct? International Journal of Salt Lake Research 6, 303-321.

Chappell, J. (1982). Evidence for smoothly falling sea levels relative to north Queensland, Australia, during the past 6000 years. Nature 302, 406-408.

510 Chenoweth, S. F. and Hughes, J.M. (1997). Genetic population structure of the catadromous Perciform: Macquaria novemaculeata (Percichthyidae). Journal of Fish Biology 50, 721-733.

Chenoweth, S. F. and Hughes, J.M. (2003). Oceanic interchange and nonequilibrium population structure in the estuarine dependent Indo-Pacific tasselfish, Polynemus sheridani. Molecular Ecology 12, 2387-2397.

Clement, M., Posada, D. and Crandall, K.A. (2000). TCS: A computer program to estimate gene genealogies. Molecular Ecology 9, 1657-1660.

Cook, B. D., Baker, A.M., Page, T.J., Grant, S.C., Fawcett, J.H., Hurwood, D.A. and Hughes, J.M. (2006). Biogeographic history of an Australian freshwater shrimp, Paratya australiensis (Atyidae): the role life history transition in phylogeographic diversification. Molecular Ecology 15, 1083-1093. 
Cook, B. D., Bunn, S.E. and Hughes, J.M. (2007). Molecular genetic and stable isotope signatures reveal complementary patterns of population connectivity in the regionally vulnerable southern pygmy perch (Nannoperca australis). Biological Conservation 138, 60-72.

Crow, J. F. and Aoki, K. (1984). Group selection for a polygenic behavioral trait: estimating the degree of population subdivision. Proceedings of the National Academy of Science 81, 6073-6077.

Dawson, M. N., Louie, K.D., Barlow, M., Jacobs, D.K. and Swift, C.C. (2002). Comparative phylogeography of sympatric sister species, Clevelandia ios and Eucyclogobius newberryi (Teleostei, Gobiidae), across the California Transition Zone. Molecular Ecology 11, 1065-1075.

DeWoody, J. A. and Avise, J.C. (2000). Microsatellite variation in marine, freshwater and anadromous fishes compared with other animals. Journal of Fish Biology 56, 461-473.

Doherty, P.J., Mather, P. and Planes, S. (1994). Acanthochromis polyacanthus, a fish lacking larval dispersal, has genetically differentiated populations at local and regional scales on the Great Barrier Reef. Marine Biology 121, 11-21.

Doherty, P. J., Planes, S. and Mather, P. (1995). Gene flow and larval duration in seven species of fish from the Great Barrier Reef. Ecology 76, 2373-2391. 
Domingues, V. S., Bucciarelli, G., Almada, V.C. and Bernardi, G. (2005). Historical colonization and demography of the Mediterranean damselfish, Chromis chromis. Molecular Ecology 14, 4051-4063.

Doukakis, P., Birstein, V.J. and De Salle, R. (2005). Intraspecific structure within three caviar-producing sturgeons (Acipenser gueldenstaedtii, A. stellatus, and Huso huso) based on mitochondrial DNA analysis. Journal of Applied Ichthyology 21, 457-460.

Doyle, J. J. and Doyle, J.L. (1987). A rapid DNA isolation procedure for small quantities of leaf tissues. Phytochemistry Bulletin 19, 11-15.

560

Durand, J. D., Tine, M., Panfili, J., Thiaw, O.T. and Lae, R. (2005). Impact of glaciations and geographic distance on the genetic structure of a tropical estuarine fish, Ethmalosa fimbriata (Clupeidae, S. Bowdich, 1825). Molecular Phylogenetics and Evolution 36, 277-287.

565

Edgar, G. J., Barrett, N.S., Graddon, D.J. and Last, P.R. (2000). The conservation significance of estuaries: a classification of Tasmanian estuaries using ecological, physical and demographic attributes as a case study. Biological Conservation 92, 383-397.

Emerson, B. C., Paradis, E. and Thebaud, C. (2001). Revealing the demographic histories of species using DNA sequences. Trends in Ecology and Evolution 16, 707-716. 
575 Excoffier, L., Smouse, P.E. and Quattro, J.M. (1992). Analysis of molecular variance inferred from metric distances among DNA haplotypes: application to human mitochondrial DNA restriction data. Genetics 131, 479-491.

Excoffier, L., Laval, G. and Schneider, S. (2005). Arlequin ver. 3.0: an integrated software package for population genetics data analysis. Evolutionary Bioinformatics Online 1, 47-50.

Farrington, L. W., Austin, C.M. and Coutin, P.C (2000). Allozyme variation and stock structure in the black bream, Acanthopagrus butcheri (Munro) (Sparidae) in southern Australia: implications for fisheries management, aquaculture and taxonomic relationship with Acanthopagrus australis (Gunther). Fisheries Management and Ecology 7, 265-279.

Feral, J. P. (2002). How useful are the genetic markers in attempts to understand and manage marine biodiversity. Journal of Experimental Marine Biology and Ecology 268, 121-145.

Fu, Y. (1997). Statistical tests of neutrality of mutations against population growth, hitchhiking and background selection. Genetics 147, 915-925.

Gene Codes. (2000). Sequencher 4.1, Gene Codes Corporation, Ann Arbour, Michigan. 
Grantham, B. A., Eckert, G.L. and Shanks, A.L. (2003). Dispersal potential of marine invertebrates in diverse habitats. Ecological Applications 13, S108-S116.

Hadwen, W.L. and Arthington, A.H. (2007). Food webs of two intermittently open estuaries receiving [15]N-enriched sewage effluent. Estuarine, Coastal and Shelf Science 71, 347-358.

605

Hadwen, W. L., Russell, G.L. and Arthington, A.H. (2007). Gut content- and stable isotope-derived diets of four commercially and recreationally important fish species in two intermittently open estuaries. Marine and Freshwater Research 58, 363-375.

610

Hamer, P. A. and Jenkins, G.P. (2004). High levels of spatial and temporal recruitment variability in the temperate sparid Pagrus auratus. Marine and Freshwater Research 55, 663-673.

Harpending, H. C., Sherry, S.T., Rogers, A.R. and Stoneking, M. (1993). The genetic structure of ancient human populations. Current Anthropology 34, 483-496.

Hewitt, G. (2000). The genetic legacy of the Quaternary ice ages. Nature 405, 907913.

620 Huey, J. A., Hughes, J.M. and Baker, A.M. (2006). Patterns of gene flow in two species of eel-tailed catfish, Neosilurus hyrtlii and Porochilus argenteus (Siluriformes: Plotosidae), in western Queensland's dryland rivers. Biological Journal of the Linnean Society 87, 457-467. 

agent. Arbovirus Research In Australia 9, 143-147.

Hurwood, D. A. and Hughes, J.M. (1998). Phylogeography of the freshwater fish, Mogurnda adspersa, in streams of northeastern Queensland, Australia: evidence for altered drainage patterns. Molecular Ecology 7, 1507-1517.

Hurwood, D. A. and Hughes, J.M. (2001). Historical interdrainage dispersal of eastern rainbowfish from the Atherton Tableland, north-eastern Australia. Journal of Fish Biology 58, 1125-1136.

635

Johnson, M. S. (2000). Measuring and interpreting genetic structure to minimize the genetic risks of translocation. Aquaculture Research 31, 33-43.

Klanten, O.S., Choat. J.H. and van Herwerden, L. (2007). Extreme genetic diversity 640 and temporal rather than spatial portioning in a widely distributed coral reef fish. Marine Biology 150, 659-670.

Lacy, R. C. (1987). Loss of genetic diversity from managed populations: interacting effects of drift, mutation, immigration, selection, and population subdivision. Conservation Biology 1, 143-158. 
Maltagliata, F. (2002). Genetic monitoring of brackish-water populations: the Mediterranean toothcarp Aphanius fasciatus (Cyprinodontidae) as a model. Marine Ecology Progress Series 235, 257-262.

650

McGlashan, D.J. and Hughes, J.M. (2000). Reconciling patterns of genetic variation with stream structure, earth history and biology in the Australian freshwater fish Craterocephalus stercusmuscarum (Atherinidae). Molecular Ecology 9, 17371751.

655

Nathan, R., Perry, G., Cronin, J.T., Strand, A.E. and Cain, M.L. (2003). Methods for estimating long-distance dispersal. Oikos 103, 261-273.

Nathan, R. (2005). Long-distance dispersal research: building a network of yellow 660 brick roads. Diversity and Distributions 11, 125-130.

Nesbo, C. L., Magnhagen, C. and Jakobsen, K.S. (1998). Genetic differentiation among stationary and anadromous perch (Perca fluviatilis) in the Baltic Sea. Hereditas 129, 241-249.

665

O'Reilly, P. T., Canino, M.F., Bailey, K.M. and Bentzen, P. (2004). Inverse relationship between FST and microsatellite polymorphism in the marine fish, walleye pollock (Theragra chalcogramma): implications for resolving weak population structure. Molecular Ecology 13, 1799-1814. 
Ovenden, J. R. and Street, R. (2003). Genetic population structure of mangrove jack, Lutjanus argentimaculatus (Forsskal). Marine and Freshwater Research 54, 127-137.

675 Page, T. J., Sharma, S. and Hughes, J.M. (2004). Deep phylogenetic structure has conservation implications for ornate rainbowfish (Melanotaeniidae : Rhadinocentrus ornatus) in Queensland, eastern Australia. Marine and Freshwater Research 55, 165-172.

680 Panov, V. E., Krylov, P.I. and Riccardi, N. (2004). Role of diapause in dispersal and invasion success by aquatic invertebrates. Journal of Limnology 63, 56-69.

Ponniah, M. and Hughes, J.M. (2006). The evolution of Queensland spiny mountain crayfish of the genus Euastacus. II. Investigating simultaneous vicariance with intraspecific genetic data. Marine and Freshwater Research 57, 349-362.

Posada, D. and Crandall, K.A. (2001). Intraspecific gene genealogies: trees grafting into networks. Trends in Ecology and Evolution 16, 37-45.

690 Purcell, J. F. H., Cowen, R.K., Hughes, C.R. and Williams, D.A. (2006). Weak genetic structure indicates strong dispersal limits: a tale of two coral reef fish. Proceedings of the Royal Society B: doi: org/10.1098/rspb.2006.3470.

Pusey, B., Kennard, M. and Arthington, A. (2004). 'Freshwater Fishes of NorthEastern Australia'. Collingwood (CSIRO Publishing). 
Riginos, C. and Nachman, M.W. (2001). Population subdivision in marine environments: the contributions of biogeography, geographical distance and discontinuous habitat to genetic differentiation in a blennioid fish, Axoclinus nigricaudus. Molecular Ecology 10, 1439-1453.

Rozas, J. and Rozas, R. (1999). DnaSP version 3: an integrated program for molecular population genetics and molecular evolution analysis. Bioinformatics Applications Note 15, 174-175.

705

Sanderson, M. J. and Donoghue, M.J. (1989). Patterns of variation in levels of homoplasy. Evolution 43, 1781-1795.

Schneider, S., Roessli, D. and Excoffier, L. (2000) Arlequin ver. 2.000: A software for population genetics analysis. Genetics and Biometry Laboratory, University of Geneva, Switzerland.

Sheaves, M., Johnston, R. and Abrantes, K. (2007). Fish fauna of dry tropical and subtropical estuarine floodplain wetlands. Marine and Freshwater Reseach 58, 931-943.

715

Slatkin, M. (1987). Gene flow and the geographic structure of natural populations. Science 236, 787-792.

Slatkin, M. and Maddison, W.P. (1990). Detecting isolation by distance using phylogenies of genes. Genetics 126, 249-260. 
Slatkin, M. (1993). Isolation by distance in equilibrium and non-equilibrium populations. Evolution 47, 264-279.

725 Slatkin, M. (1995). A measure of population subdivision based on microsatellite allele frequencies. Genetics 139, 457-462.

Spear, S. F., Peterson, C.R., Matocq, M.D. and Storfer, A. (2006). Molecular evidence for historical and recent population size reductions of tiger salamanders (Ambystoma tigrinum) in Yellowstone National Park. Conservation Genetics. doi: $10.1007 / \mathrm{s} 10592-005-9095-4$

Uthicke, S. and Benzie, J.A.H. (2003). Gene flow and population history in high dispersal marine invertebrates: mitochondrial DNA analysis of Holothuria nobilis (Echinodermata: Holothuroidea) populations from the Indo-Pacific. Molecular Ecology 12, 2635-2648.

Vrijenhoek, R. C. (1998). Conservation genetics of freshwater fish. Journal of Fish Biology 53, 394-412.

740 Ward, R. D. and Elliot, N.G. (2001). Genetic population structure of species in the South East Fishery of Australia. Marine and Freshwater Research 52, 563-573.

Waters, J. M., Dijkstra, L.H. and Wallis, G.P. (2000). Biogeography of a southern hemisphere freshwater fish: how important is marine dispersal? Molecular Ecology 9, 1815-1821. 
Waters, J.M., Allibone, R.M. and Wallis, G.P. (2006). Geological subsidence, river capture, and cladogenesis of galaxiid fish lineages in central New Zealand. Biological Journal of the Linnean Society 88, 367-376.

750

Watts, R. J. and Johnson, M.S. (2004). Estuaries, lagoons and enclosed embayments: habitats that enhance population subdivision of inshore fishes. Marine and Freshwater Research 55, 641-651.

755 Weir, B. S. and Cockerham, C.C. (1984). Estimating F-statistics for the analysis of population structure. Evolution 38, 1358-1370.

Williamson, C. E. (1993). Linking predation risk models with behavioral mechanisms: identifying population bottlenecks. Ecology 74, 320-331.

Wong, B. B. M., Keogh, J.S. and McGlashan, D.J. (2004). Current and historical patterns of drainage connectivity in eastern Australia inferred from population genetic structuring in a widespread freshwater fish Pseudomugil signifer (Pseudomugilidae). Molecular Ecology 13, 391-401.

Wright, S. (1943). Isolation by distance. Genetics 28, 114-138.

Zardoya, R., Castilho, R., Grande, C., Favre-Krey, L., Caetano, S., Marcato, S., Krey, G. and Patarnellos, T. (2004). Differential population structuring of two closely related fish species, the mackerel (Scomber scombrus) and the chub mackerel 
(Scomber japonicus), in the Mediterranean Sea. Molecular Ecology 13, 17851798.

775

780

785 


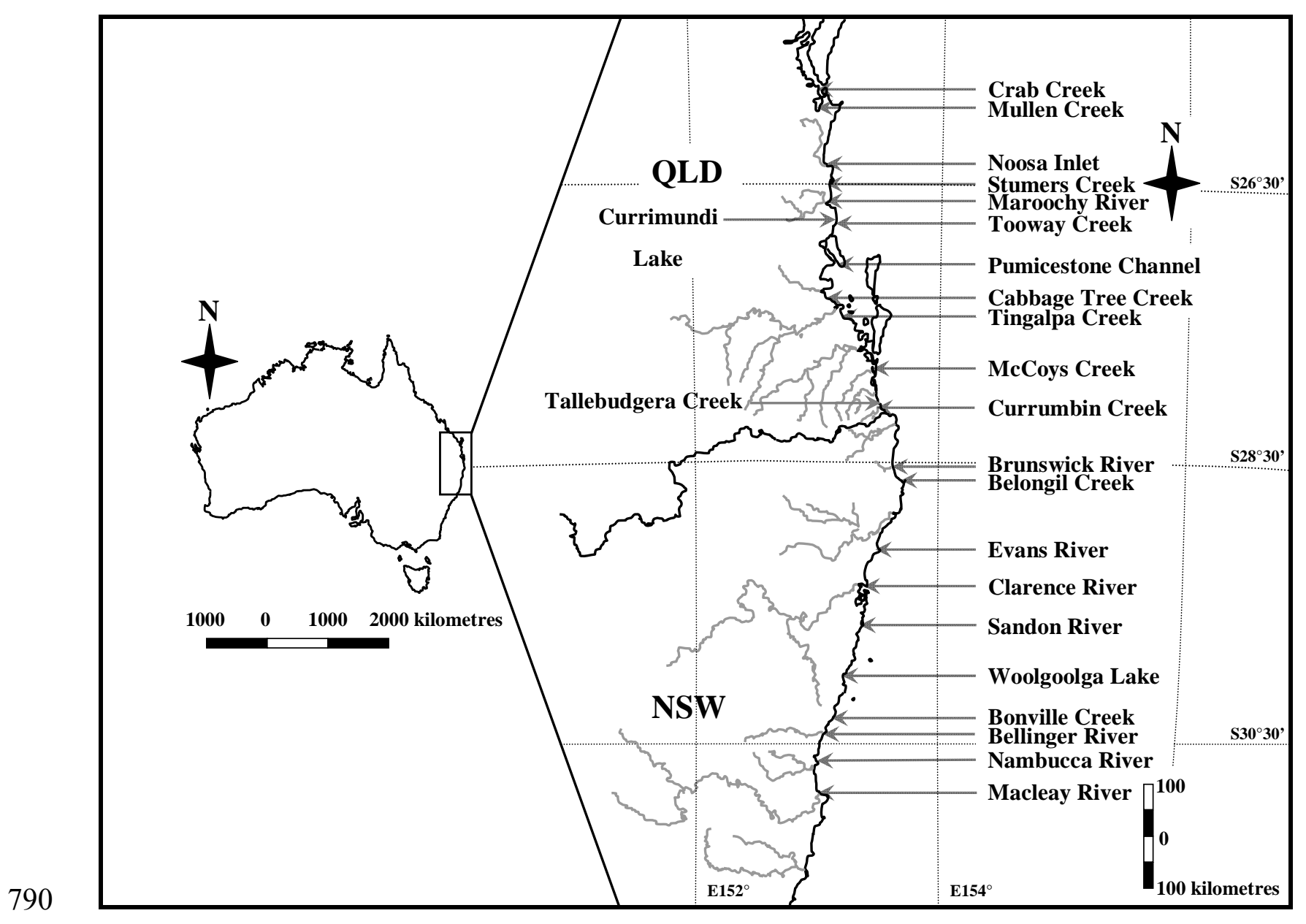

Figure 1. Map of east coast of Australia, showing the 23 sites sampled for $A$. marianus and A. jacksoniensis across Queensland and New South Wales. 


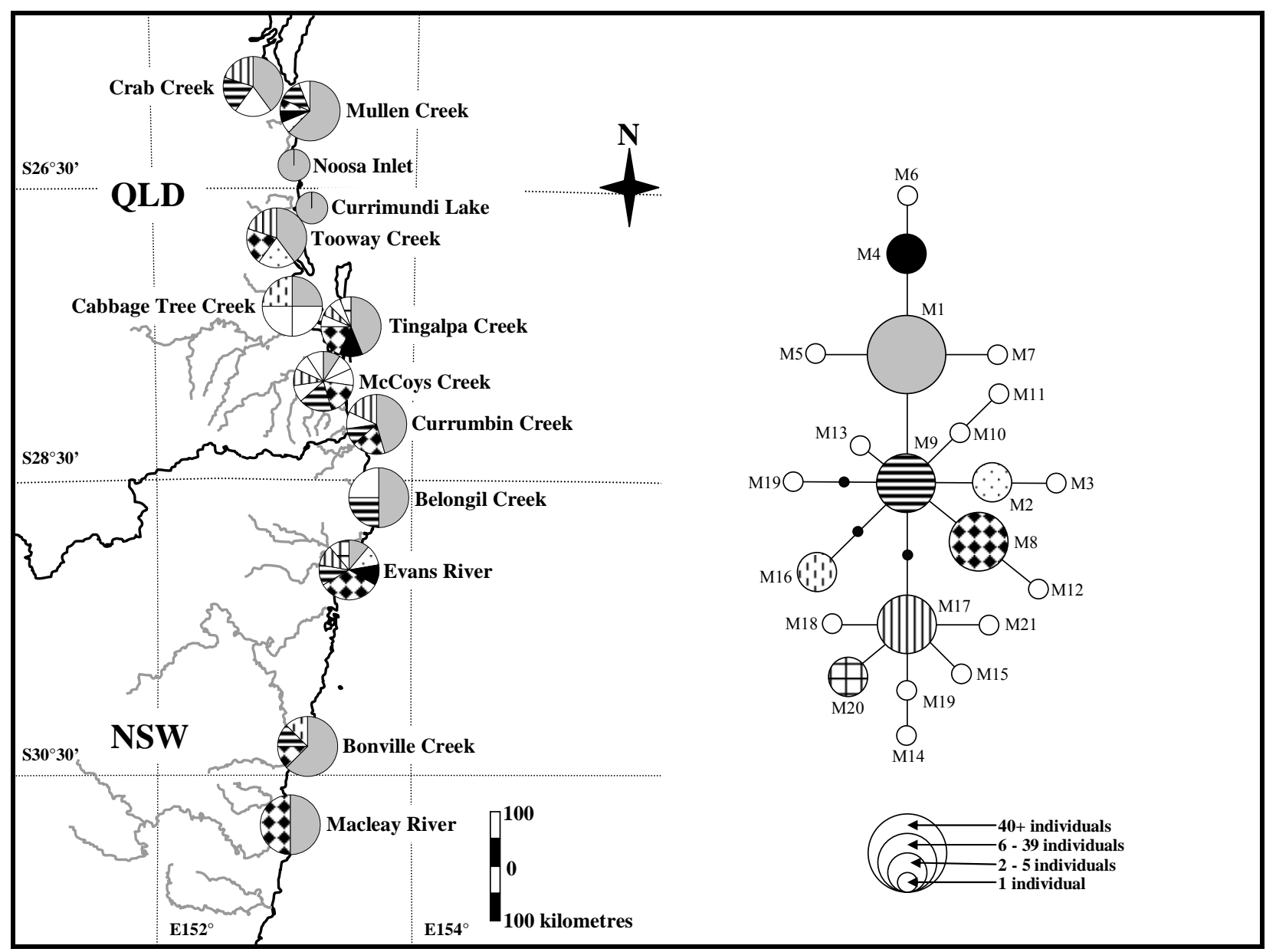

Figure 2. Geographic distribution of $A$. marianus relative haplotype frequencies along the east coast of Australia, with shading indicating corresponding network haplotype. Haplotype network for A. marianus, with circle size corresponding to sample size. Small black dots indicate haplotypes that were not sampled, or have become extinct through genetic drift. White circles indicate singletons. 


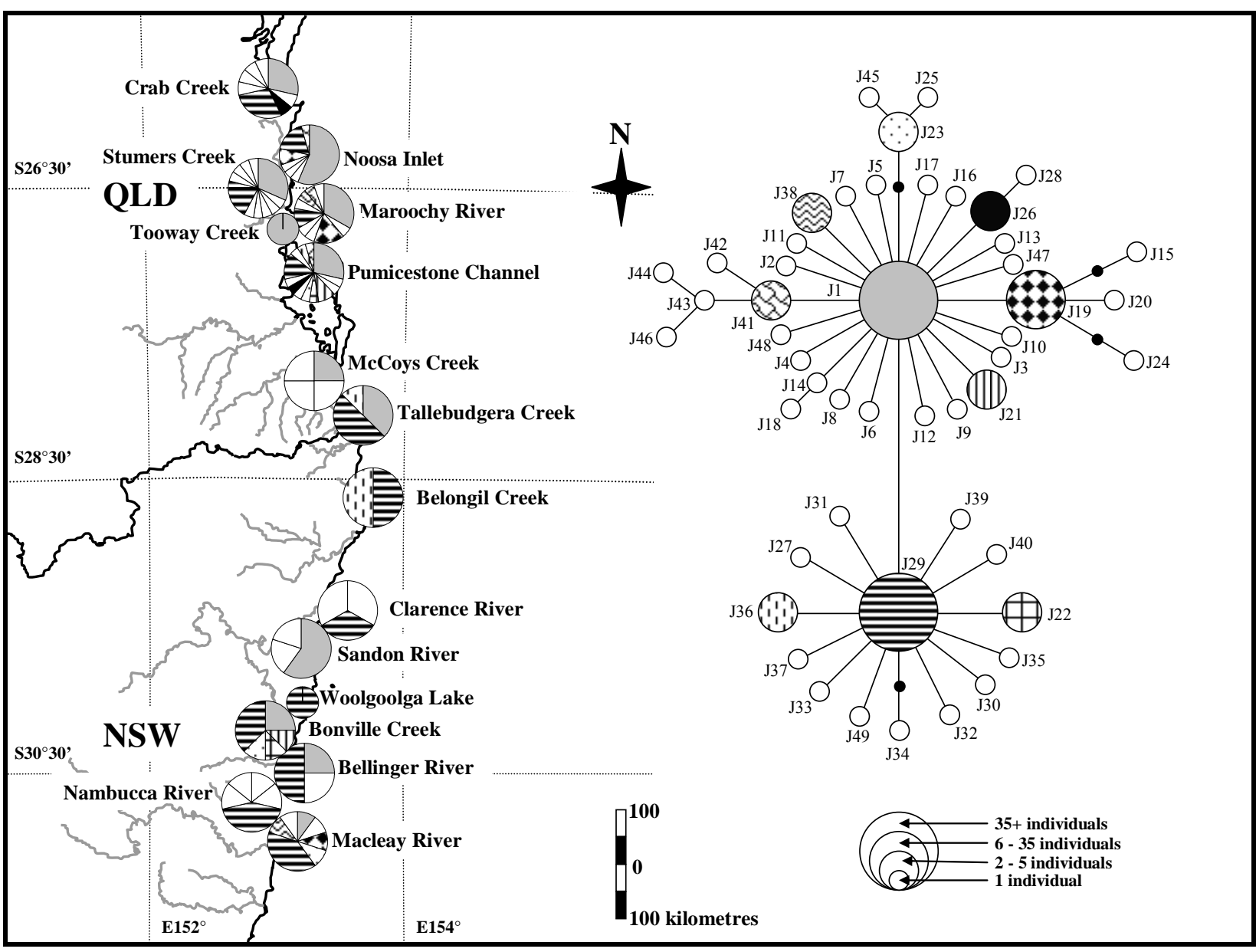

805

Figure 3. Geographic distribution of A.jacksoniensis relative haplotype frequencies along the east coast of Australia, with shading indicating corresponding network haplotype. Haplotype network for A. jacksoniensis, with circle size corresponding to 810 sample size. Small black dots indicate haplotypes that were not sampled, or have become extinct through genetic drift. White circles indicate singletons.

Table 1. Diversity values for A. marianus and A. jacksoniensis in eastern Australia showing overall $F_{\mathrm{ST}}$ (based on haplotypes frequencies), overall $\Phi_{\mathrm{ST}}$ (based on

815 pairwise differences in genetic divergence) and Mantel test correlation coefficients.

\begin{tabular}{ccccccc}
\hline Species & \multicolumn{2}{c}{ Overall $\boldsymbol{F}_{\mathrm{ST}}$} & \multicolumn{2}{c}{ Overall $\boldsymbol{\Phi}_{\mathrm{ST}}$} & \multicolumn{2}{c}{ Mantel Test } \\
\hline & $F$-statistic & $P$-value & $\Phi$-statistic & $P$-value & Correlation Coefficient & $P$-value \\
A. marianus & 0.019 & 0.205 & 0.013 & 0.300 & 0.081 & 0.238 \\
A. jacksoniensis & 0.017 & 0.124 & 0.020 & 0.106 & 0.107 & 0.106 \\
\hline
\end{tabular}

Table 2. Neutrality and raggedness indices for A. marianus and A. jacksoniensis in eastern Australia.

\begin{tabular}{ccccccc}
\hline Species & \multicolumn{3}{c}{ Tests of Neutrality } & \multicolumn{2}{c}{ Mismatch Distributions } \\
\hline & Tajima's D & P-value & $F u$ 's $F_{S}$ & P-value & Raggedness Index & $P$-value \\
A. marianus & -1.429 & 0.046 & -12.779 & 0.000 & 0.020 & 0.083 \\
A. jacksoniensis & -2.364 & 0.000 & -72.737 & 0.000 & 0.069 & 0.933 \\
\hline
\end{tabular}


Table 3. Haplotype distributions and sample sizes for $A$. marianus. Grey shading indicates sampled sites where $A$. marianus was not captured. 


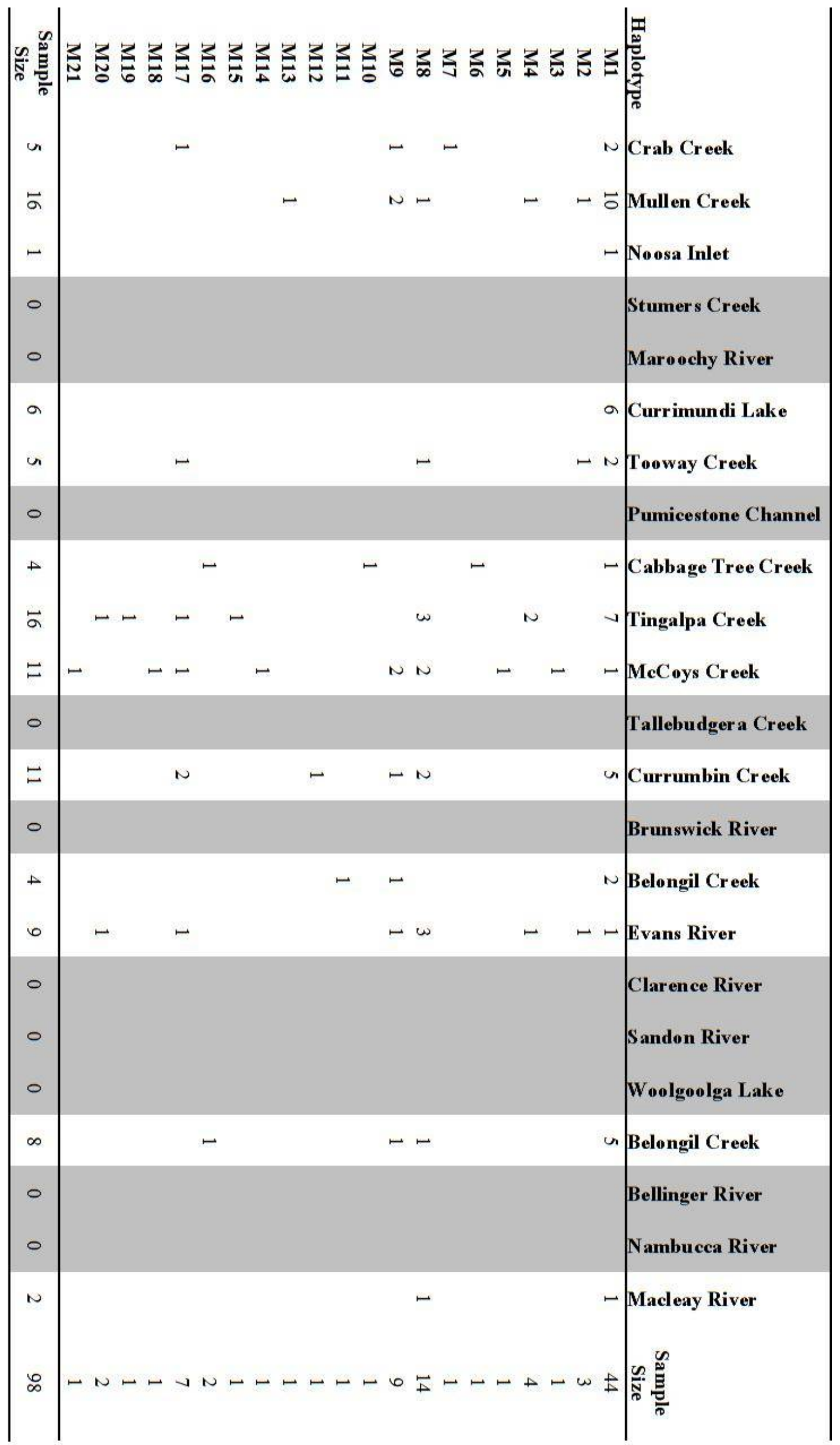


Table 4. Haplotype distributions and sample sizes for $A$. jacksoniensis. Grey shading indicates sampled sites where $A$. jacksoniensis was not captured. 


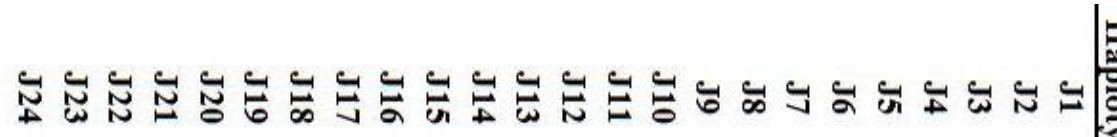

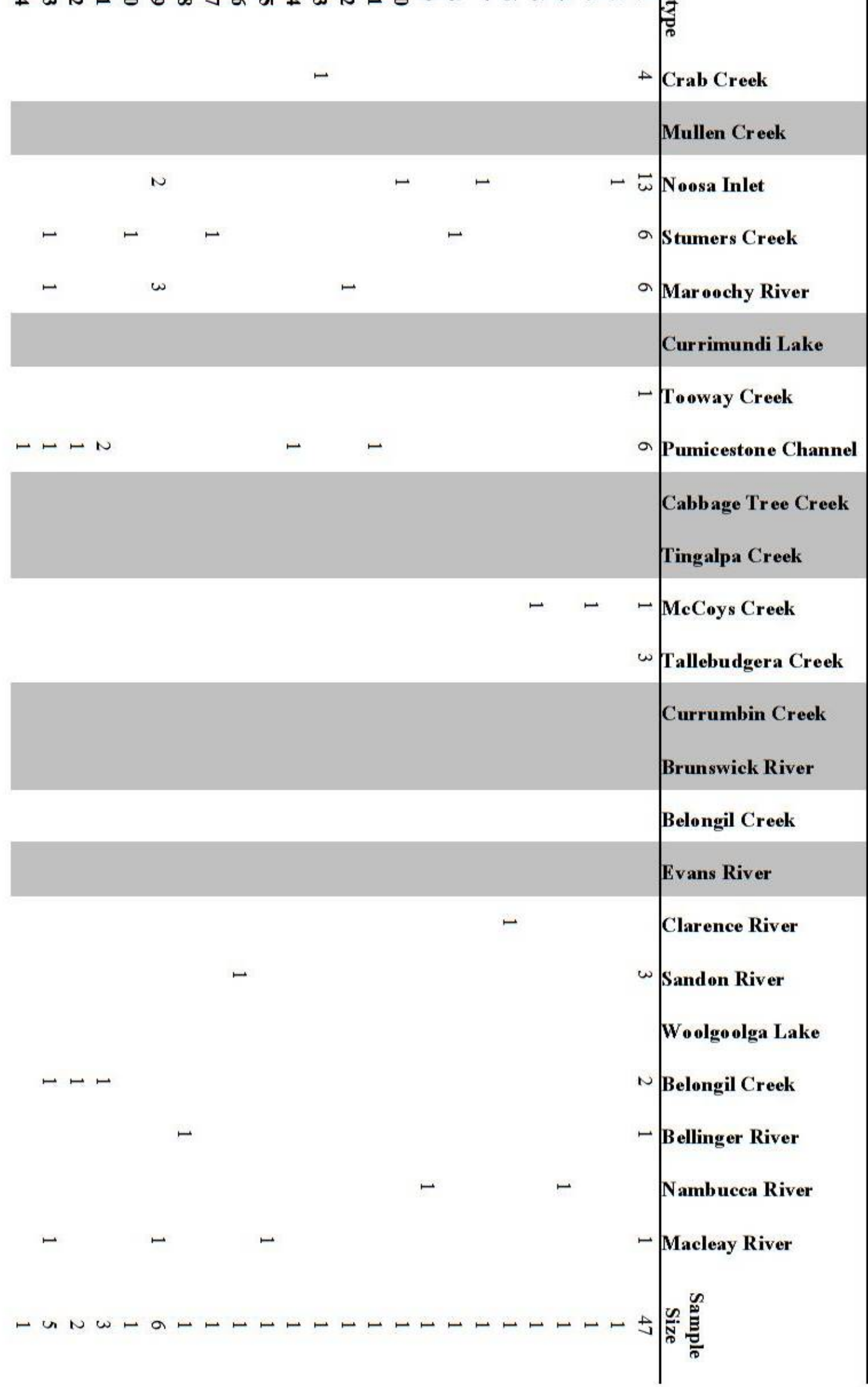




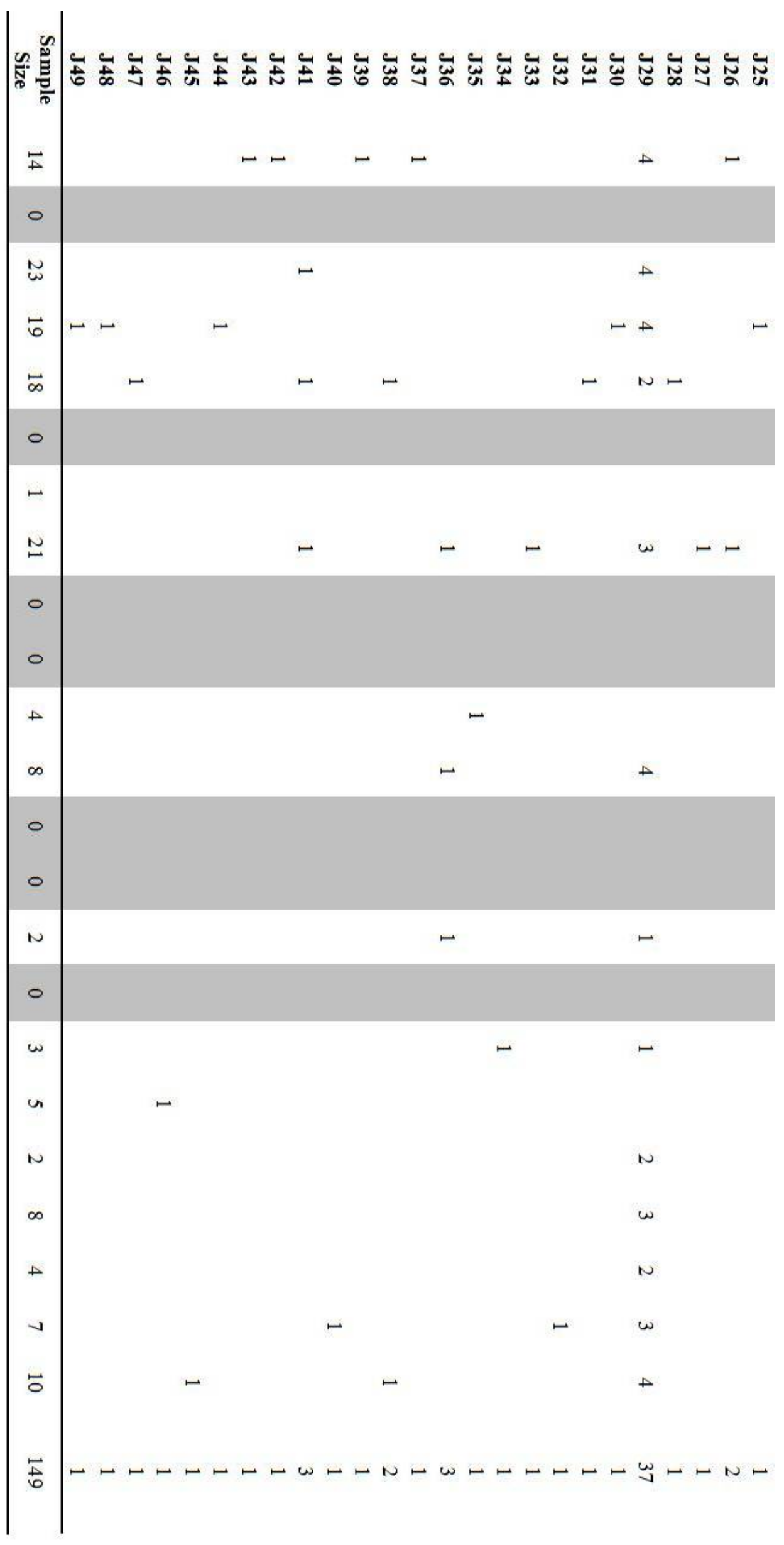

